\title{
Postoperative Rehabilitation after Hallux Valgus Surgery: A literature review
}

\author{
by Massimiliano Polastri, PT ${ }^{1 \otimes}$
}

\section{The Foot and Ankle Online Journal 4 (6): 4}

Background: Hallux valgus deformity is a common condition and several surgical treatments are discussed in the literature. The main purpose of this study is to review the literature concerning rehabilitation treatment following hallux valgus surgery.

Methods: The present literature review is performed by searching the following databases: PubMed and Embase using the Medical Subject Headings terms 'hallux valgus', 'postoperative rehabilitation', 'surgical procedures' matched by the Boolean operator AND; The Cochrane Library using 'hallux valgus', 'postoperative rehabilitation' matched by the Boolean operator AND; and PEDro using 'hallux valgus'.

Results: The initial search identified ninety-four citations, and of those, eighty-five were excluded because they were related to surgical techniques, including percutaneous access and/or different osteotomy modalities, to radiological evaluations before and after the correction to describe the deformity, to surgical complications or to anesthesia management. Study design, patients, outcome measures, and the main results were extracted. After the selection, nine documents related to rehabilitation were included.

Discussion: The findings of this review indicated that areas peripheral to the surgery, such as the ankles and toes (second to fifth) should be included in the rehabilitation program. Treatment may include physical instruments as magnetic fields in order to manage pain and edema postoperatively. In the included studies, American Orthopedic Foot and Ankle Society (AOFAS) score, range of motion, and visual analogic scale were mainly used as tools for evaluating outcomes.

Conclusion: Postoperative rehabilitation timeframe may vary depending on the surgical technique and can be performed in an outpatient setting. The use of appropriate footwear that allows safe walking and does not compromise the surgical result is important immediately after surgery. Postoperative rehabilitation is mainly oriented to encourage both plantar pressure on the first ray and joint mobility. It also represents an important component of recovery following the correction of hallux valgus deviation, where it helps to restore physiological gait and foot function.

Key words: Hallux Valgus, Motion Therapy, Postoperative Rehabilitation, Prevalence, Surgical Procedures.

$\mathrm{H}$ allux valgus deformity (HVD) is a common condition $^{1-12}$ and several surgical treatments are discussed in literature. ${ }^{13-19}$

\footnotetext{
Address correspondence to: Massimiliano Polastri, Unità Operativa Medicina Fisica e Riabilitazione, Azienda Ospedaliero-Universitaria di Bologna, Policlinico Sant'Orsola-Malpighi, Via G. Massarenti, 9. 40138 Bologna, Italy.

${ }^{1}$ Unit of Physical Medicine and Rehabilitation, Bologna University Hospital, St. Orsola-Malpighi Polyclinic, 40138 - Bologna, Italy.
}

A study of the prevalence of forefoot and hallux valgus surgery in Sweden found that hallux valgus was by far the most common forefoot surgery and that it was performed more in urban than rural regions, and in private clinics than in community hospitals. ${ }^{20}$ 


\begin{tabular}{|c|c|c|c|}
\hline Database & $\begin{array}{l}\text { Citations } \\
\text { (n) }\end{array}$ & $\begin{array}{l}\text { Selected } \\
\text { (n) }\end{array}$ & MeSH* terms \\
\hline PubMed & 38 & 9 & $\begin{array}{c}\text { hallux valgus and postoperative rehabilitation and } \\
\text { surgical procedures }\end{array}$ \\
\hline Embase & 42 & 1 & $\begin{array}{c}\text { hallux valgus and postoperative rehabilitation and } \\
\text { surgical procedures }\end{array}$ \\
\hline The Cochrane Library & 3 & 2 & hallux valgus and postoperative rehabilitation \\
\hline PEDro & 11 & 1 & hallux valgus \\
\hline Total & 94 & $9^{f}$ & \\
\hline
\end{tabular}

* MeSH Medical Subject Headings, $\boldsymbol{E}$ the selected citations in Embase, The Cochrane Library and PEDro were also present in PubMed. Nine references were retained for the final review.

Table 1 Search's criteria and number of studies in the review.

In 2007, Saro and colleagues reported that quality of life following surgical correction of HVD was not influenced by the severity of the deformity. ${ }^{21}$ The aim of the present study was to review the literature concerning rehabilitation treatment following hallux valgus surgery. The main purpose of this review was to determine the need to perform the postoperative rehabilitation (PR) after the corrective surgery of the hallux valgus.

\section{Methods}

The present review sourced literature from database searches of PubMed and Embase using the Medical Subject Headings (MeSH) terms 'hallux valgus', 'postoperative rehabilitation', 'surgical procedures' using the Boolean operator AND; The Cochrane Library using the MeSH terms 'hallux valgus', 'postoperative rehabilitation' with the Boolean operator AND; and PEDro using the MeSH term 'hallux valgus'. The MeSH terms were different for each database to allow the author to obtain the greatest number of citations. (Table 1) The search was performed between October of 2010 and November of 2010 with no limits on the date setting. Studies were included if they a) were written in English, Italian, German, or French; b) were related to therapeutic exercises; and c) investigated patients with hallux valgus-related surgery.

In one case, the English abstract of a paper in German was read. Potentially relevant studies were identified by searching titles and abstracts, and then the full text of the selected articles was reviewed.

\section{Results}

The initial search identified ninety-four citations, and of those, eighty-five were excluded because they were related to surgical techniques. This included percutaneous access and/or different osteotomy modalities, to radiological evaluations before and after the correction to describe the deformity, to surgical complications or to anesthesia management. Study design, patients, outcome measures, and the main results were extracted. After the selection, nine documents focusing on rehabilitation were included in the present review. The included studies were conducted in Europe and North America. Only two experimental studies related to rehabilitation were found (Table 2). Most of the papers were descriptive in nature and small-sample studies were mainly present among the selected reports. Four were non experimental (Table 3) and three had low level evidence to rehabilitation (Table 4). 


\begin{tabular}{|c|c|}
\hline Authors & Simoncini \& coll. (2001) \\
\hline Study design & Double blind study. \\
\hline \multirow[b]{2}{*}{ Outcome measures } & $\begin{array}{l}20 \text { patients underwent undefined hallux valgus surgery who complained symptoms from about } \\
\text { two years. Immediately after surgery, two magnetic bars were applied under the bandage } \\
\text { creating a variable magnetic field of } 100-150 \mathrm{G} \text { for } 30 \text { days. Patients were blind about the side } \\
\text { in which magnetic bars were applied. These were put only in the right side being the left the } \\
\text { control. After the first control at } 30 \text { days, shoes including magnetic bars (only in the right side) } \\
\text { were dressed for more } 30 \text { days. }\end{array}$ \\
\hline & $\begin{array}{l}\text {-VAS at } 2,30,60 \text { days. } \\
\text {-Edema evaluation at } 2 \text { and } 60 \text { days. }\end{array}$ \\
\hline Main results & $\begin{array}{l}\text { VAS right side: } \\
-2 \text { days: } 8 \text { pts. } \\
-30 \text { days: } 2 \text { pts. } \\
-60 \text { days: } 1 \text { pts. } \\
\text { Edema right side: } \\
-2 \text { days: reduction of } 0.5 \mathrm{~cm} \text { in } 12 \text { patients } \\
-60 \text { days: better function reduction in feeling of heaviness } \\
\text { VAS left side (control): } \\
-2 \text { days: } 8 \text { pts. } \\
-30 \text { days: } 4 \text { pts. } \\
-60 \text { days: } 3 \text { pts. } \\
\text { Edema left side (control): } \\
-2 \text { days: in } 20 \text { people there is no reduction } \\
-60 \text { days: in } 20 \text { people feeling of heaviness persist. }\end{array}$ \\
\hline Authors & Connor \& coll. (1995) \\
\hline Study design & Randomized controlled trial. \\
\hline Patients & $\begin{array}{l}39 \text { patients underwent Austin osteotomy. All were placed in walkers immediately after surgery } \\
\text { and were instructed to ice and elevate their feet during the first } 72 \text { hrs. One group received } \\
\text { physical therapy and continuous passive motion. The control group received physical therapy } \\
\text { only. In the CPM group, treatment starts } 24 \text { hrs. after surgery for eight hrs. daily until the 24th } \\
\text { day increasing ROM to } 20^{\circ} \text { (flexion) and } 65^{\circ} \text { (extension). All received } 20 \text {-min hydrotherapy } \\
\text { treatments three times weekly from second to fourth week. }\end{array}$ \\
\hline Outcome measures & $\begin{array}{l}\text { ROM: } \\
\text {-measurements were taken on seven occasion and the initial was intraoperatively on the } 7 \text { th, } \\
14 \text { th, } 21 \text { st, } 28 \text { th, } 60 \text { th and } 90 \text { th days. } \\
\text {-Return to conventional shoes. }\end{array}$ \\
\hline Main results & $\begin{array}{l}\text { ROM: } \\
\text {-The group who received CPM had a significantly larger mean ROM }(p<0.05) \text { at every point } \\
\text { thereafter. } \\
\text {-There was no significant difference between initial and final mean extension in the CPM group. } \\
\text {-There was significant difference between initial extension and final extension in the physical } \\
\text { therapy only group }(p<0.001) \text {. } \\
\text {-There was no significant difference between initial and final flexion in the two groups. } \\
\text {-The CPM group returned to wearing conventional shoes significantly earlier }(p<0.001) \text {. }\end{array}$ \\
\hline
\end{tabular}

Table 2 Experimental studies.

PR postoperative rehabilitation, CPM continuous passive motion, ROM range of motion, $\mathbf{G}$ gauss (the unit of the magnetic flux density), VAS visual analogic scale. 


\begin{tabular}{|c|c|}
\hline Authors & Schuh \& coll. (2010) \\
\hline $\begin{array}{l}\text { Study } \\
\text { desian }\end{array}$ & Prospective study. \\
\hline Patients & $\begin{array}{l}29 \text { patients with mild to moderate hallux valgus underwent Chevron osteotomy, were assessed. All wore } \\
\text { Rathgeber shoe for four weeks postoperatively. All received therapeutic instructions and a special } \\
\text { compression sock in order to manage the immediate postoperative period. At four weeks after surgery } \\
\text { they received multimodal rehabilitation program including cryotherapy, lymphatic drainage, manual } \\
\text { interventions of the first MTP joint, muscle stretching and gait training, once a week for three to six } \\
\text { weeks. }\end{array}$ \\
\hline $\begin{array}{l}\text { Outcome } \\
\text { measures }\end{array}$ & $\begin{array}{l}\text {-Plantar pressure distribution parameters } \\
\text {-AOFAS score } \\
\text {-ROM of first MTP joint }\end{array}$ \\
\hline Main results & $\begin{array}{l}\text { Two patients were lost at the follow-up, the final sample was } 27 \text { people. } \\
\text { Increase in mean maximum force in the great toe: } \\
\text {-from } 72.2 \mathrm{~N} \text { preop. to } 106.8 \mathrm{~N} \text { at one year }(\mathrm{p}=<0.05) \text {. } \\
\text { Increase in mean contact area in the great toe: } \\
\text {-from } 7.6 \mathrm{~cm} 2 \text { preop. to } 8.9 \text { at one year }(\mathrm{p}=<0.05) \text {. } \\
\text { Increase in mean maximum force in the first metatarsal head region: } \\
\text {-from } 122.5 \mathrm{~N} \text { preop. to } 144.7 \text { at one year. } \\
\text { Increase in AOFAS score: } \\
\text {-from } 61 \text { points preop. to } 94 \text { at final follow-up }(\mathrm{p}=<0.001) \text {. } \\
\text { Hallux valgus angle average measurement: } \\
\text {-from } 31 \text { degrees preop. to } 9 \text { degrees at one year }(\mathrm{p}=<0.001) \text {. } \\
\text { ROM average of the first MTP: } \\
\text {-from } 14 \text { degrees preop. to } 6 \text { degrees at one year }(\mathrm{p}=0.001) \text {. }\end{array}$ \\
\hline Authors & Schuh \& coll. (2009) \\
\hline $\begin{array}{c}\text { Study } \\
\text { design }\end{array}$ & Prospective study. \\
\hline Patients & $\begin{array}{l}30 \text { patients underwent the Scarf }(n=10) \text { osteotomy if intermetatarsal angle was more than } 16 \text { degrees } \\
\text { and underwent Austin }(n=20) \text { osteotomy if it was less than } 16 \text { degrees. All complained of pain in the } \\
\text { region of the first MTP joint preop. Postop. all were placed in the Rathgeber shoe for four weeks and } \\
\text { received a special sock that reduce swelling. PR started four weeks after surgery. Elevation, lymphatic } \\
\text { drainage, activation of the muscle pump and cryotherapy were used. The stance phase was trained } \\
\text { followed by } \\
\text { weight bearing of the first MTP joint during midstance and terminal stance. Selective strengthening of the } \\
\text { peroneus longus muscle was performed. Manual treatment was focused on an improvement of flexion and } \\
\text { extension of the first MTP joint including also mobilization of the Lisfranc, transverse tarsal, subtalar and } \\
\text { ankle joints. All received a mean of } 4.4 \text { treatment session once a week for three to six weeks ranged from } \\
35 \text { to } 45 \text { minutes each. }\end{array}$ \\
\hline $\begin{array}{l}\text { Outcome } \\
\text { measures }\end{array}$ & $\begin{array}{l}\text {-Pedobarographic analysis preoperatively and four, eight weeks and six months after surgery. } \\
\text {-Metatarsophalangeal-interphalangeal score of the AOFAS preop. and six months after surgery. } \\
\text {-ROM measurement of the first MTP joint preop. and six months after surgery. }\end{array}$ \\
\hline Main results & $\begin{array}{l}28 \text { were available for follow-up. } \\
\text { Metatarsophalangeal-interphalangeal score of the AOFAS: } \\
\text {-From } 60.7 \text { to } 94.5 \text { at six months. } \\
\text { ROM of the first MTP joint: } \\
\text {-Mean dorsiflexion increased from } 40.4 \text { degree to } 45.9 \text { at six months. } \\
\text {-Mean plantar flexion was } 28.5 \text { preop. and } 27.4 \text { at six months. }\end{array}$ \\
\hline
\end{tabular}

Table 3 Non experimental studies. (More on next page)

PR postoperative rehabilitation, AOFAS American Orthopaedic Foot and Ankle Score, ROM range of $\square$ motion, MTP metatarsophalangeal, $\mathbf{k P a}$ kilopascal $\left(\mathrm{Pa}\right.$ : unit of pressure $\left.=1 \mathrm{Newton} / \mathrm{m}^{2} ; 1 \mathrm{kPa}=1000 \mathrm{~Pa}\right), \mathbf{C P M}$ continuous passive motion, $\mathbf{N}$ Newton. 
Table 3 (continue)

\begin{tabular}{|c|c|}
\hline Authors & Schuh \& coll. (2008) \\
\hline $\begin{array}{l}\text { Study } \\
\text { desian }\end{array}$ & Prospective study. \\
\hline Patients & $\begin{array}{l}33 \text { patients with a mild to moderate hallux valgus deformity. } 22 \text { underwent Austin osteotomy and } 11 \\
\text { Scarf osteotomy. Patients wore Rathgeber shoe for four weeks postoperatively. PR starts after four } \\
\text { weeks. }\end{array}$ \\
\hline $\begin{array}{l}\text { Outcome } \\
\text { measures }\end{array}$ & $\begin{array}{l}\text {-Pedobarographic analysis at four, eight weeks and a six months. } \\
\text {-AOFAS and ROM measurement of the first MTP joint prior the surgery and at six months } \\
\text { postoperatively. } \\
\text {-Pts satisfaction at six months. }\end{array}$ \\
\hline Main results & $\begin{array}{l}\text { Increase in big toe pressure: } \\
\text {-after eight weeks from } 80.7 \mathrm{kPa} \text { to } 171.9 \mathrm{kPa} \\
\text {-at six months postoperatively } 336.1 \mathrm{kPa} \text {. } \\
\text { Increase in the first metatarsal head pressure: } \\
\text {-after eight weeks from } 141.4 \mathrm{kPa} \text { to } 215.8 \mathrm{kPa} \\
\text {-at six months postop. } 292.7 \mathrm{kPa} \text {. } \\
\text { AOFAS score: } \\
\text {-from } 60.8 \text { preoperatively to } 94.0 \text { at six months. } \\
\text { ROM of the first } M T P \text { joint: } \\
\text {-from } 66^{\circ} \text { preop. to } 70^{\circ} \text { at six months. }\end{array}$ \\
\hline Authors & Connor and Berk (1994) \\
\hline $\begin{array}{l}\text { Study } \\
\text { design }\end{array}$ & Descriptive study. \\
\hline Patients & $\begin{array}{l}\text { Ten patients in whom hallux limitus was observed after undefined hallux valgus surgery were evaluated } \\
\text { with pain and stiffness of the first MTP joint. The patients starts CPM after six months from surgery. All } \\
\text { were instructed to utilize CPM device at home for four hr. per day for } 28 \text { days. Three out ten patients } \\
\text { required hallux limitus corrective surgery due to persistent pain and discomfort (they were excluded from } \\
\text { the investigation). }\end{array}$ \\
\hline $\begin{array}{l}\text { Outcome } \\
\text { measures }\end{array}$ & $\begin{array}{l}\text {-ROM of the first MTP joint (flexion and extension) at } 28,48 \text { and } 90 \text { days. } \\
\text {-Weight bearing radiographs at the initial examination. }\end{array}$ \\
\hline Main results & $\begin{array}{l}\text { Initial mean extension: } \\
-32.5 \pm 7.8 \text { degree. } \\
\text { Final extension: } \\
-41.5 \pm 10.0 \text { degree. } \\
\text { Initial mean flexion: } \\
-2.5 \pm 2.5 \text { degree. } \\
\text { Final flexion: } \\
-6.0 \pm 3.7 \text { degree. }\end{array}$ \\
\hline
\end{tabular}

Table 3 Non experimental studies. (Continued from previous page)

PR postoperative rehabilitation, AOFAS American Orthopaedic Foot and Ankle Score, ROM range of motion, MTP metatarsophalangeal, $\mathbf{k P a}$ kilopascal $\left(\mathrm{Pa}\right.$ : unit of pressure $=1 \mathrm{Newton} / \mathrm{m}^{2} ; 1 \mathrm{kPa}=1000 \mathrm{~Pa}$ ), $\mathbf{C P M}$ continuous passive motion, $\mathbf{N}$ Newton. 


\begin{tabular}{|c|c|}
\hline Authors & Unver \& coll. (2004) \\
\hline \multirow{2}{*}{$\begin{array}{l}\text { Study } \\
\text { design } \\
\text { Patients }\end{array}$} & Case report. \\
\hline & $\begin{array}{l}\text { The use of a special type of orthosis was described in one patient with bilateral hallux valgus deformity } \\
\text { underwent McBride operation. It was allowed to walk on the first day after surgery, the orthosis was } \\
\text { applied for six weeks. Exercises for second to fifth toes and ankle joints were encouraged from the first } \\
\text { day postop. Mobilization of the great toe was included after six weeks. }\end{array}$ \\
\hline $\begin{array}{l}\text { Outcome } \\
\text { measures }\end{array}$ & $\begin{array}{l}\text {-Right hallux valgus angle preop. } 57 \text { degrees. } \\
\text {-Right intermetatarsal angle preop. } 13 \text { degrees. } \\
\text {-Left hallux valgus angle preop. } 40 \text { degrees. } \\
\text {-Left intermetatarsal angle preop. } 14 \text { degrees. }\end{array}$ \\
\hline Main results & $\begin{array}{l}\text {-Right hallux valgus angle postop. } 27 \text { degrees. } \\
\text {-Right intermetatarsal angle postop. } 8 \text { degrees. } \\
\text {-Left hallux valgus angle postop. } 27 \text { degrees. } \\
\text {-Left intermetatarsal angle postop. } 13 \text { degrees. }\end{array}$ \\
\hline Authors & Scott Weil and Benton-Weil (1998) \\
\hline \multirow{4}{*}{$\begin{array}{c}\text { Study } \\
\text { design } \\
\text { Patients } \\
\text { Outcome } \\
\text { measures } \\
\text { Main results }\end{array}$} & $\begin{array}{l}\text { Description of one exercise after undefined hallux valgus surgery. The patient plantar flexes the hallux } \\
\text { against the resistance of the exercise band. This is carried out for four weeks. }\end{array}$ \\
\hline & $\mathrm{N} / \mathrm{A}$ \\
\hline & N/A \\
\hline & N/A \\
\hline Authors & Donnery and DiBacco (1990) \\
\hline \multirow{4}{*}{$\begin{array}{l}\text { Patients } \\
\text { Outcome } \\
\text { measures } \\
\text { Main results }\end{array}$} & $\begin{array}{l}\text { Description of the exercise program after undefined hallux valgus surgery. Motion between bone } \\
\text { fragments will lead to delayed union or nonunion despite the best intentions. Exercise instruction and } \\
\text { program supervision are often delegated to the physiotherapist. Personal communication with the } \\
\text { therapist about the specific procedures performed is always recommended. }\end{array}$ \\
\hline & N/A \\
\hline & N/A \\
\hline & N/A \\
\hline
\end{tabular}

Table 4 Low level evidence studies.

N/A not applicable.

\section{Discussion}

In order to understand if the PR is necessary after the surgical correction of the hallux valgus, a literature review was performed. Among those included, was a recent study by Schuh, et al., which adds a significant meaning to the matter. Their findings, observed in a medium-long term, showed significant improvements in weight bearing in the forefoot region as well as in the American Orthopedic Foot and Ankle Society (AOFAS) score at the follow-up one year after the surgery. ${ }^{22}$ According to these authors, PR should improve outcome after surgical correction of hallux valgus deviation.
It is possible to assume that change of the angular values in the first metatarsophalangeal (MTP) joint should develop alterations in forefoot biomechanics.

In fact, the reduction on maximum force in this region should shift the weight bearing, over the time, toward the others metatarsal heads (second to fifth) developing a potential secondary metatarsal pain. On the other hand, one may consider PR as a necessary pathway to prevent and eventually treat this condition. 
This includes restoring weight bearing in the first ray which is a necessary condition in order to maintain equilibrium of the biomechanical forces in the forefoot. The authors also describe the rehabilitation approach's including different modalities.

In 2009, Schuh, et al., performed a pedobarographic analysis to investigate the function of the big toe and first ray concluding that PR helps to restore the physiological gait pattern after the Austin or Scarf osteotomy. ${ }^{23}$ Connor and Berk used continuous passive motion (CPM) to recover range of motion (ROM) of flexion and extension in patients who had surgical complications. ${ }^{24}$ Their results demonstrated that joint mobility is reduced as a consequence of surgery. The association between hallux valgus surgery and iatrogenic hallux limitus highlights the importance of conserving and restoring mobility of the first MTP joint. The authors did not describe the type of surgery that caused the hallux limitus. CPM reduced the pain, and joint mobility was sufficiently restored to prevent a second surgery, even when the therapy was started 6 months after surgery. These findings lead one to speculate that if CPM, although passive, could improve ROM in subjects with surgical complications; the motion would aid functional recovery in people who had no complications following common corrective procedures of hallux valgus. As discussed by Connor, et al., the primary benefits of starting rehabilitative treatment with CPM immediately after surgery are related to the prevention of the adhesions and a quick return to the conventional shoes. ${ }^{25}$ In a prospective study, Schuh, et al., found that rehabilitation treatment increased big toe function and restored the physiological gait pattern in patients who underwent Austin or Scarf osteotomy to correct mild to moderate deviations. ${ }^{26}$ The pedobarographic analysis showed improvement in the AOFAS score and an increase in plantar pressure following a rehabilitation regimen starting 4 weeks after the surgery. Subjects included in this study wore Rathgeber shoes during the first 4 weeks. Unver, et al., developed an orthosis with a 3-mm polyethylene thermoplastic sheet and a velcro strap to maintain the surgical correction and reduce the risk of complications in subjects who underwent McBride osteotomy. $^{27}$
The Authors emphasized the importance of postoperative rehabilitation after a 6 -week period. Among the selected, this study recommended the earliest mobilization of the ankle and second to fifth toes, starting from the first day after surgery.

Donnery and DiBacco suggested a group of simple exercises that could be integrated into the postoperative treatment of patients who underwent McBride hallux abducto valgus reduction. ${ }^{28}$ The Authors recommended that patients perform active ROM exercises beginning 3-4 weeks after surgery. In contrast, Weil and Benton-Weil described a technique in which patients performed a series of exercises that encouraged plantar flexion starting 1 week after surgery. ${ }^{29}$ Simoncini, et al., used magnetic fields to reduce pain and edema in the short term after hallux valgus surgery. ${ }^{30}$ Physiotherapists are aware in the daily clinical practice of postoperative edema and pain. In the study of these authors, controls did not receive the treatment in allowing them to assume its effectiveness. Furthermore, Simoncini, et al., are the first to introduce this issue confirming the importance of a treatment to include physical instruments. ${ }^{30}$

Before drawing the final conclusions one should reflect on the possibility to prevent surgery in people with HVD. Torkki and coll. (2001), first in literature, have conducted a randomized controlled trial on a sample of 209 people with mild to moderate HVD in order to compare two different treatment modalities: surgery (chevron procedure) or orthosis. ${ }^{31}$ They concluded that the surgical treatment was more effective and it resulted in a better cosmetic result if compared with the orthosis. However, the orthotic treatment may be considered an option while waiting for the surgery.

Recently, John and Willis published a paper on a series of ten patients (six with hallux valgus and four with hallux varus) treated with a dynamic splint. ${ }^{32}$ Both the study design and the sample size, did not allow to draw firm conclusions about their findings. The authors describe deformity corrections of ten degree at one month in patients with HVD. 
The findings of this literature review indicate that other areas of the foot unrelated to the surgery, such as the ankle and toes (second to fifth) should be included in the rehabilitation program. In the studies reviewed, AOFAS score, ROM measurement, and VAS were mainly used as tools for evaluating outcomes.

PR is not necessarily related to the onset of surgical complications but contributes to restoring function even in presence of good surgical results. A potential limitation of this study is the restricted number of citations. A second limit is represented by the age of some sources that were published more than ten years ago. Again, some have a low evidence level and only one, among experimentals, has a control without treatment.

\section{Conclusion}

In the present literature review, nine studies on rehabilitation therapy in subjects who had undergone hallux valgus surgery were discussed. The results suggest that the PR timeframe may vary depending on the surgical technique and can be performed in an outpatient setting.

Furthermore, PR should be an important component of recovery following the correction of HVD, where it helps to restore physiological gait and foot function; from the review emerged that PR is mainly oriented to encourage both plantar pressure on the first ray and joint mobility. The use of appropriate footwear that allows safe walking and does not compromise the surgical result is important immediately after the surgery. Management of edema and pain must be also achieved. Consultation between orthopedic surgeon and physiotherapist, about the surgical technique used, is advisable before starting rehabilitation. PR after the hallux valgus surgical correction is rarely described in the literature, however, highlighting what was discussed, one should consider that it is necessary to recover foot function. More comparative experimental studies are needed.

\section{Acknowledgements}

The author thanks Professor Mauro Di Bari, at the University of Florence, for critical reading of this manuscript. Furthermore, Dr. Stefano Cantagalli, orthopedic surgeon at the Bologna University Hospital St. Orsola-Malpighi Polyclinic, for his support on hallux valgus surgery topic.

\section{References}

1. Cho NH, Kim S, Kwon DJ, Kim HA. The prevalence of hallux valgus and its association with foot pain and function in a rural Korean community. JBJS 2009 91B: 494 - 498.

2. Roddy E, Zhang W, Doherty M. Prevalence and associations of hallux valgus in a primary care population. Arthritis Rheum 2008 59: $857-862$.

3. Coughlin MJ, Jones CP. Hallux valgus: demographics, etiology, and radiographic assessment. Foot Ankle Int 2007 28: $759-777$.

4. Yu GV, Sellers CS, Shook JE, Karlock LG: Iatrogenic deformities of the first ray. Clin Podiatr Med Surg 1996 13: 367 $-422$.

5. Kusumoto A, Suzuki T, Kumakura C, Ashizawa K. A comparative study of foot morphology between Filipino and Japanese women, with reference to the significance of a deformity like hallux valgus as a normal variation. Ann Hum Biol 1996 23: 373 - 385.

6. Michelson J, Easley M, Wigley FM, Hellmann D: Foot and ankle problems in rheumatoid arthritis. Foot Ankle Int 1994 15: $608-613$.

7. Hung LK, Ho YF, Leung PC: Survey of foot deformities among 166 geriatric inpatients. Foot Ankle 1985; 5(4): 156 - 164. 8. Gottschalk FA, Solomon L, Beighton PH: The prevalence of hallux valgus in South African males. S Afr Med J 1984 65: 725 726.

9. Gottschalk FA, Beighton PH, Solomon L: The prevalence of hallux valgus in three South African populations. S Afr Med J 1981 60: 655 - 656.

10. Gottschalk FA, Sallis JG, Beighton PH, Solomon L. A comparison of the prevalence of hallux valgus in three South African populations. S Afr Med J 1980 57: 355 - 357.

11. Halebian JD, Gaines SS. Juvenile hallux valgus. J Foot Surg 1983 22: 290 - 293.

12. Shine IB. Incidence of hallux valgus in a partially shoewearing community. Br Med J 1965 1(5451): 1648 - 1650. 13. Giannini S, Vannini F, Faldini C, Bevoni R, Nanni M, Leonetti D: The minimally invasive hallux valgus correction (S.E.R.I.). Interact Surg 2007 2: 17 - 23. 
14. O'Donnell T, Hogan N, Solan M, Stephens MM. Correction of severe hallux valgus using a basal chevron osteotomy and distal soft tissue release. Foot Ankle Surg 2010 16: 126 - 131. 15. Robinson AHN, Limbers JP: Modern concepts in the treatment of hallux valgus. JBJS 2005 87B: 1038 - 1045.

16. Pinney S, Song K, Chou L. Surgical treatment of mild hallux valgus deformity: the state of practice among academic foot and ankle surgeons. Foot Ankle Int 2006 27: 970 - 973.

17. Pinney S, Song K, Chou L. Surgical treatment of severe hallux valgus deformity: the state of practice among academic foot and ankle surgeons. Foot Ankle Int 2006 27: 1024 - 1029. 18. Bauer T, Biau D, Lortat-Jacob A, Hardy P. Percutaneous hallux valgus correction using the Reverdin-Isham osteotomy. Orthop Traumatol Surg Res. 2010 96: 407 - 416.

19. Waizy H, Stukenborg-Colsman C, Abbara-Czardybon M, Emmerich J, Windhagen H, Frank D. A special soft tissue procedure for treatment of hallux valgus. Oper Orthop Traumatol 2011; 23: 46 - 51.

20. Saro C, Bengtsson AS, Lindgren U, Adami J, Blomqvist P. Surgical treatment of hallux valgus and forefoot deformities in Sweden: a population-based study. Foot Ankle Int 2008 29: 298 $-304$.

21. Saro C, Jensen I, Lindgren U, Fellander-Tsai L. Quality of life outcome after hallux valgus surgery. Qual Life Res 2007 16: $731-738$.

22. Schuh R, Adams S, Hofstaetter SG, Krismer M, Trnka HJ. Plantar loading after chevron osteotomy combined with postoperative physical therapy. Foot Ankle Int. 2010 31: 980 986.

23. Schuh R, Hofstaetter SG, Adams SB Jr, Pichler F, Kristen $\mathrm{KH}$, Trnka HJ. Rehabilitation after hallux valgus surgery: importance of physical therapy to restore weight bearing of the first ray during the stance phase. Phys Ther 2009 89: 934 - 945. 24. Connor C, Berk DM. Continuous passive motion as an alternative treatment for iatrogenic hallux limitus. J Foot Ankle Surg. 1994 33: 177 - 179.

25. Connor JC, Berk DM, Hotz MW. Effects of continuous passive motion following Austin bunionectomy. A prospective review. JAPMA 1995 85: 744 - 748.

26. Schuh R, Hofstaetter SG, Kristen KH, Trnka HJ. Effect of physiotherapy on the functional improvement after hallux valgus surgery-a prospective pedobarographic study. Z Orthop Unfall 2008 146: 630 - 635.

27. Unver B, Sampiyon O, Karatosun V, Gunal I, Angin S.

Postoperative immobilisation orthosis for surgically corrected hallux valgus. Prosthet Orthot Int 2004 28: 278 - 280.

28. Donnery J, DiBacco RD. Postsurgical rehabilitation exercises for hallux abducto valgus repair. JAPMA 1990 80: 410 $-413$.

29. Weil LS, Benton-Weil W. Postoperative hallux valgus exercises. J Foot Ankle Surg 1998 37: 355.

30. Simoncini L, Giuriati L, Giannini S: Clinical evaluation of the effective use of magnetic fields in podology. Chir Organi Mov 2001 86: 243 - 247.

31.Torkki M, Malmivaara A, Seitsalo S, Hoikka V, Laippala P, Paavolainen P. Surgery vs orthosis vs watchful waiting for hallux valgus. A randomized controlled trial. JAMA 2001 285: 2474 2480.

32.John MM, Willis FB. Dynamic splinting for hallux valgus and hallux varus: a pilot study. FAOJ 2010 3(1): 1. 